Acta vet. scand. 1973, 14, 147-159.

From the Department of Microbiology and Immunology and the Department of Pathology, Veterinary College of Norway, Oslo.

\title{
THE EFFECTS \\ OF FEEDING PEPTIDE-PRECIPITATING LIGNOSULPHONIC ACIDS IN VARIOUS CONCENTRATIONS TO GROWING PIGS
}

\author{
By \\ Bjørn Næss and Morten Fjølstad
}

\begin{abstract}
NÆSS, BJØRN and MORTEN FJØLSTAD: The effects of feeding peptide-precipitating lignosulphonic acids in various concentrations to growing pigs. Acta vet. scand. 1973, 14, 147-159. - It is shown that lignosulphonic acids, at a concentration of $13 \%$ in conventional feed given to growing pigs, lead to a marked reduction in the weight gain.

When given $3 \%$ and $6 \%$ lignosulphonic acids in the feed, no effects on the weight gain were observed as compared to the controls. The weight gain reduction caused by lignosulphonic acids at high levels in the feed is discussed in relation to the inhibitory effects of these acids on a number of biological systems which have been studied previously.
\end{abstract}

lignosulphonic acids; growing pigs; proteinases in feces; nitrogen in feces.

Lignosulphonic acids are present in various types of animal fodder. As adhesives in the pelletizing of animal feeds, lignosulphonic acids have commonly been used in concentrations of up to $3 \%$ (Brüggemann et al. 1964, Eberhardt 1964, Jansen 1964).

Jantzen (1967) has proposed the use of dried protein-lignosulphonic acid precipitates, derived from protein-containing waste fluids with specially prepared lignosulphonic acids, as animal feed. The content of lignosulphonic acids in such complexes with proteins may be $10-20 \%$ (Jantzen; Hildrum \& Næss 1972). 
The use of sulphite spent liquor powder containing high concentrations of lignosulphonic acids as a food additive has also been proposed (Pietz 1967). Furthermore, lignosulphonic acids are found in single cell protein produced from sulphite spent liquor (Næss \& Slagsvold 1973).

It has been shown that lignosulphonic acids inhibit the effects of a number of biologically active substances in vitro, including various animal and microbial proteinases, colicins and bacterial toxins (Næss et al. $1973 \mathrm{a}, \mathrm{b}$; Niess \& Sandvik 1973).

The aim of the present work was to study the possible toxic effects of lignosulphonic acids fed in high concentrations to growing pigs, and in the case of toxic effects occurring, to try to estimate a safe level for lignosulphonic acids in the feed.

\section{MATERIALS AND METHODS}

Lignosulphonic acids (LSA). The sodium salt of LSA, prepared by the procedure of Jantzen (1967), was kindly supplied by Alwatech A/S, Oslo, Norway. The sulphur content of the LSA was $6 \%$. Gel chromatography and peptide-precipitating ability determinations of the LSA fractions were carried out as described previously (Næss et al. $1973 \mathrm{~b}$ ).

Pigs. Weaned Norwegian Landrace pigs of both sexes, randomly selected from several sources, and initially weighing from 21 to $30 \mathrm{~kg}$, were used.

Diet composition. During the last nine days before the experiment started, the pigs were gradually adapted, from conventional feed to the final diet, which consisted of: Herring meal, $5 \%$; soy bean meal (extracted), $9 \%$; wheat meal, $10 \%$; barley meal, $45 \%$; oat meal, $20 \%$; wheat bran, $8.9 \%$; calcium, $0.7 \%$; phosphorus, $0.6 \%$; salts (calculated as sodium cloride), $0.4-0.5 \%$; other minerals, $0.7 \%$. Vitamins were supplied as follows (per $\mathrm{kg}$ feed): Vitamin $A, 3000$ i.u.; vitamin $D_{3}, 375$ i.u.; vitamin $E$, $30 \mathrm{mg}$; vitamin $B_{2}, 3 \mathrm{mg}$. In addition $15.0 \mathrm{~kg}, 6.4 \mathrm{~kg}$ or $3.1 \mathrm{~kg}$ LSA were added per $100 \mathrm{~kg}$ (final concentrations $13 \%, 6 \%$ and $3 \%$ respectively). The feed given to the pigs in the control groups was the basic diet without lignosilphonic acids.

Housing, feeding and necropsy. The experiments were conducted within closed buildings, with the pigs confined in pens, hand-fed (not individual feeding) twice a day, and given adequate 
water supply. The animals were weighed once a week and the feed rations regulated according to the norms given by Heje (1972). The pigs receiving LSA were given these as additions to the normal basic ration.

Experiment 1. Twenty-two pigs were randomly divided into two groups of 11, and confined in pens with five or six pigs in each. The experimental group received $13 \%$ LSA in the feed. The other group was used as control. The experimental pigs were killed after nine or 12 weeks of the experiment, after which necropsies were performed. Microscopical examinations were carried out on the following organs: Skeletal muscle, cardiac muscle, liver, lung, kidney, adrenal gland, thyroid gland, stomach, jejunum, colon, mesenteric lymph nodes, pancreas and ribs. The organ pieces were fixed in $10 \%$ neutral formalin, embedded in paraffin, sections cut at approx. $5 \mu$ thick, and stained with hematoxylin and eosin, and with van Gieson's stain.

Experiment 2. Twenty-four pigs were randomly divided into three groups of eight pigs and confined in pens with eight in each. The three groups were randomly selected to receive $0 \%, 3 \%$ and $6 \%$ of LSA in the feed. After 11 weeks the experiment was terminated. Samples for microscopical investigations were taken from the following organs: Skeletal muscle, cardiac muscle, liver, kidney and colon.

Chemical examinations. Feces were collected from the pigs receiving $13 \%$ LSA, and from the controls after six weeks and when killed. Feces from the pigs receiving 6 and $3 \%$ LSA were collected after eight and 10 weeks of the experiment. Samples of feces, LSA and the fodder were examined for total nitrogen*. Analyses for the determination of blood in the feces were performed using Occultest and Hematest orthotolidin discs * (Oser 1965 ). Analyses for colour reactions on the addition of various concentrations of different salts $\left(\mathrm{MgSO}_{4}, \mathrm{CuSO}_{4}, \mathrm{CaCO}_{8}, \mathrm{FeSO}_{4}\right)$ to LSA solutions were carried out using a photometer ** at 600 nm using LSA solutions as blank.

- Statens landbrukskjemiske kontrollstasjon, Moss, Norway.

* Ames Company, Bucks., England.

* Spectronic 20, Bausch \& Lomb, Rochester, USA. 
Enzyme determinations. The casein precipitation method (the CP-method) of Sandvik (1962) was used for the quantitative analyses of proteinases in the feces of the pigs. For the qualitative analyses of proteinases in the feces, a specific antiproteinase was produced against swine trypsin (from Koch-Light ${ }^{\star}$ ) in rabbit as described by Sandvik, and the electrophoretic Casein Precipitation Inhibition test (electrophoretic CPI-test) (Fossum 1970) used for the separation of the antiproteinases, and the naturally occurring proteinase inhibitors in the immune serum. By this procedure, the naturally occurring inhibitors are localized in the $\alpha$ - and $\beta$-globulins, on the anode side of the line of application, while the inhibition due to induced antibodies occurs in the region of the $\gamma$-globulins. After transferring the serum electrophorogram from the paper electrophoresis strip (LKB equipment for paper electrophoresis, LKB, Stockholm, Sweden) to a caseinate agar plate (Sandvik), the plates were incubated with filter paper strips moistened with feces content. Zones of inhibition of the enzyme-produced precipitation occurred where inhibitors or antiproteinases were present. The enzymes used were trypsin from swine pancreas (crystallized, batch no. 47506, from KochLight), proteinase from Bacillus thuringiensis (ATCC ${ }^{\star}{ }^{\star} 10792$ ) and feces from the pigs prepared as follows: One $\mathrm{ml}$ of feces was added to $1 \mathrm{ml}$ of water and the mixture thoroughly shaken and centrifuged. The supernatant was used as enzyme solution without further purification.

\section{Experiment 1}

\section{RESULTS}

Clinical. When $13 \%$ LSA was given in the pigs' feed, a marked reduction in the weight gain was seen. Four of the pigs had to be killed three weeks before the planned end of the experimental period. These four pigs gradually became thinner and miserable, and after having weighed $22,21,26$ and $28 \mathrm{~kg}$ at the start of the experiment, their weights after nine weeks of the experiment were 24, 17, 23 and $16 \mathrm{~kg}$, respectively. Results of experiment 1 are summarized in Table 1 and in Fig. 1. It can be seen that the weights after 12 weeks of the experiment were sub-

* Koch-Light Laboratories Ltd., Colnbrook, Bucks., England.

* American Type Culture Collection, Rockville, Maryland, USA. 
T a ble 1. Live-weights, daily weight gain and concentration of proteinases in the feces of the pigs receiving $13 \%$ lignosulphonic acids in the diet, compared to the control pigs.

\begin{tabular}{|c|c|c|c|c|c|}
\hline Pig no. & $\begin{array}{l}\text { Live-weight } \\
\text { at experiment } \\
\text { start }(\mathrm{kg})\end{array}$ & $\begin{array}{l}\text { Live-weight } \\
\text { at experiment } \\
\text { end }(\mathrm{kg})\end{array}$ & $\begin{array}{l}\text { Time of } \\
\text { experiment } \\
\text { (days) }\end{array}$ & $\begin{array}{l}\text { Daily weight } \\
\text { gain }(\mathbf{k g})\end{array}$ & $\begin{array}{c}\text { Amount of pro- } \\
\text { teinases in feces } \\
\text { (diffusion } \\
\left.\text { units } / 25 \mu^{1}\right)\end{array}$ \\
\hline 3 & 22 & 24 & 62 & 0.02 & 60 \\
\hline 5 & 21 & 17 & 62 & - & 60 \\
\hline 7 & 26 & 23 & 62 & - & 16000 \\
\hline 8 & 28 & 16 & 62 & - & 60 \\
\hline 1 & 27 & 61 & 84 & 0.40 & 32000 \\
\hline 2 & 26 & 52 & 84 & 0.31 & 30 \\
\hline 4 & 23 & 59 & 84 & 0.43 & 1000 \\
\hline 6 & 26 & 41 & 84 & 0.18 & 250 \\
\hline 9 & 25 & 65 & 84 & 0.48 & 500 \\
\hline 10 & 24 & 61 & 84 & 0.44 & 8000 \\
\hline 11 & 23 & 55 & 84 & 0.38 & 1000 \\
\hline $\mathrm{m} . \pm \mathrm{s}$ & $\begin{array}{c}24.6 \pm 2.2 \\
\text { (pigs nos. } \\
3,5,7, \text { and } 8 \\
\text { excluded) }\end{array}$ & $\begin{array}{c}56.3 \pm 8.0 \\
\text { (pigs nos. } \\
3,5,7 \text { and } 8 \\
\text { excluded) }\end{array}$ & & $\begin{array}{c}0.37 \pm 0.10 \\
\text { (pigs nos. } 3,5,7 \\
\text { and } 8 \text { excluded) }\end{array}$ & 5360 \\
\hline $\begin{array}{l}\mathrm{m} . \pm \mathrm{s} \text { of } \\
\text { the control } \\
\text { group }\end{array}$ & $25.1 \pm 1.8$ & $79.9 \pm 8.9$ & & $0.65 \pm 0.10$ & 4 \\
\hline
\end{tabular}

stantially greater in the controls than in the pigs receiving LSA in the diet. The pigs ate the amount of feed given in all cases. The experimental pigs had diarrhea most of the time with darkcoloured feces (almost black). Compared to the controls the pigs receiving $13 \%$ LSA did not thrive. A blue colour reaction of approximately the same degree was obtained with feces from both experimental and control pigs, and also with the feed, using the Occultest and Hematest orthotolidin discs.

Large amounts of proteinases were detected using the CPmethod, in the feces from some of the pigs receiving $13 \%$ LSA in the diet. Only traces of proteinases were detected in feces from the control pigs. Using the CPI-test (Fig. 2), it was shown that the major part of the proteinases demonstrated in the feces was inhibited by antibodies against swine trypsin, indicating that trypsin was the predominating proteolytic enzyme in the feces. 


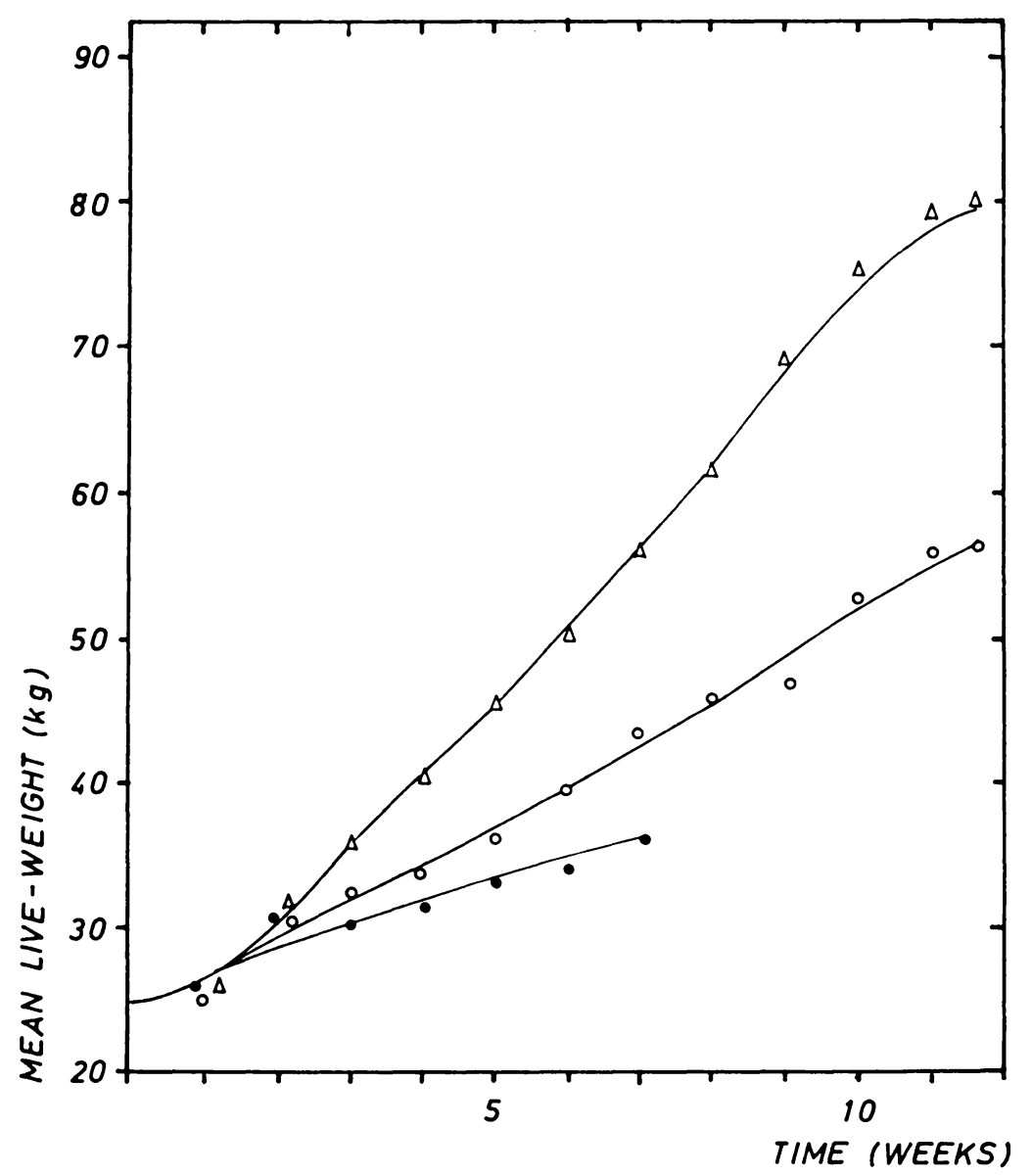

F i g u r e 1. Live-weight of pigs receiving $13 \%$ lignosulphonic acids in the diet ( -0 , all experimental pigs included $),(\mathrm{O}-\mathrm{O}$ four pigs killed early excluded), and weight gain of control pigs $(\triangle \longrightarrow \Delta)$.

A significant difference $(P \leq 0.05)$ between the content of nitrogen in the feces of pigs in the experimental and control groups was found (based on dry weight and corrected for the content of LSA, and for the content of nitrogen $(0.29 \%)$ in the LSA).

Necropsy. The pigs in the experimental group showed more, or less, poorly developed skeletal musculature. The contents of colon and the lower part of jejunum had an almost watery consistency, and black colour. The mucosa of the colon was hyperemic. In the histological examinations of pigs nos. 3, 5, 7 and 8 , it 


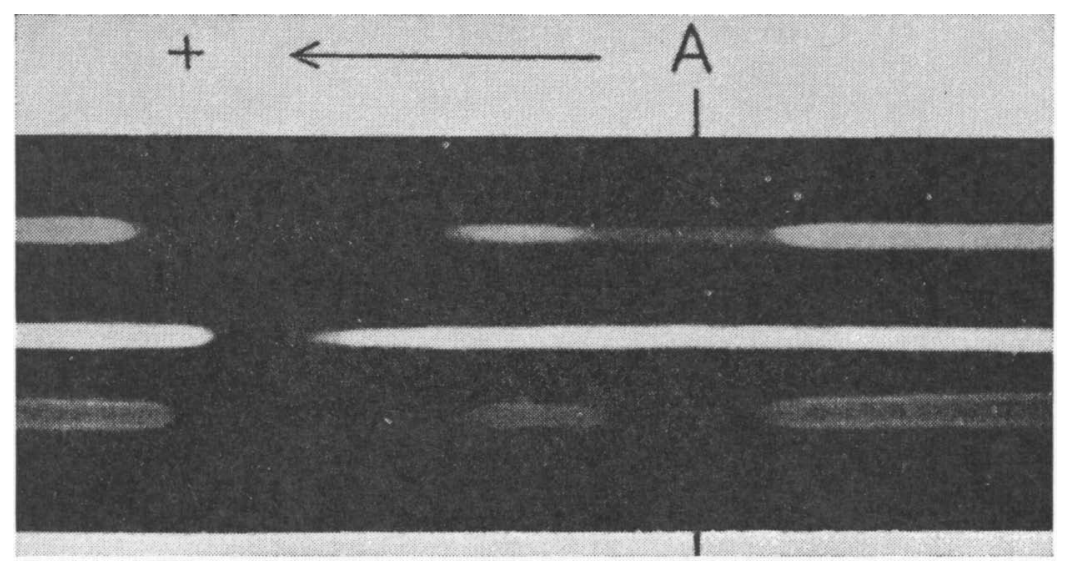

Figur e 2. Electrophoretic CPI-test with anti-swine trypsin. The enzymes used are (downwards): Feces from pig no. 1 (diluted $\frac{1}{64}$ ), proteinase from Bacillus thuringiensis (negative control), and swine trypsin $(0.005 \mathrm{mg}$ per $\mathrm{ml})$. Electrophoresis was carried out in $0.05 \mathrm{M}$ phosphate buffer at $\mathrm{pH} 6.2$ for $18 \mathrm{hrs}$. The zones of inhibition near the line of application (A) are due to antienzymes in the $\gamma$-globulin fractions, while the zones of inhibition on the anode side are due to the naturally occurring inhibitors in rabbit serum.

was found that the liver cells were greatly swollen, with distortion of the normal laminar structure. The cytoplasma of these cells was vacuolated. The liver cells of the remaining pigs were also swollen, but to a lesser extent, and the cytoplasma had a granular appearance. Some of the pigs, especially those killed late in the experiment, seemed to have some proliferation of connective tissue, particularly in the portal area. A moderate proliferation of the reticulo-endothelial cells was found in some livers. The myocardium of all the pigs showed a proliferation of the nuclei of the muscle cells, and in some places the nuclei showed a pronounced tendency to form rows. A considerable part of these nuclei were greatly swollen, and some had uneven borders. The chromatin was condensed along the long axis in some of the nuclei. The nuclei of the skeletal muscle cells of some of the pigs had proliferated. A major part of the glomeruli had shrunk, to some degree, in all the pigs. In some kidneys, a few tubuli had swollen epithelial cells with vacuolated cytoplasm and, in some cases, the nuclei of these cells were pycnotic. 


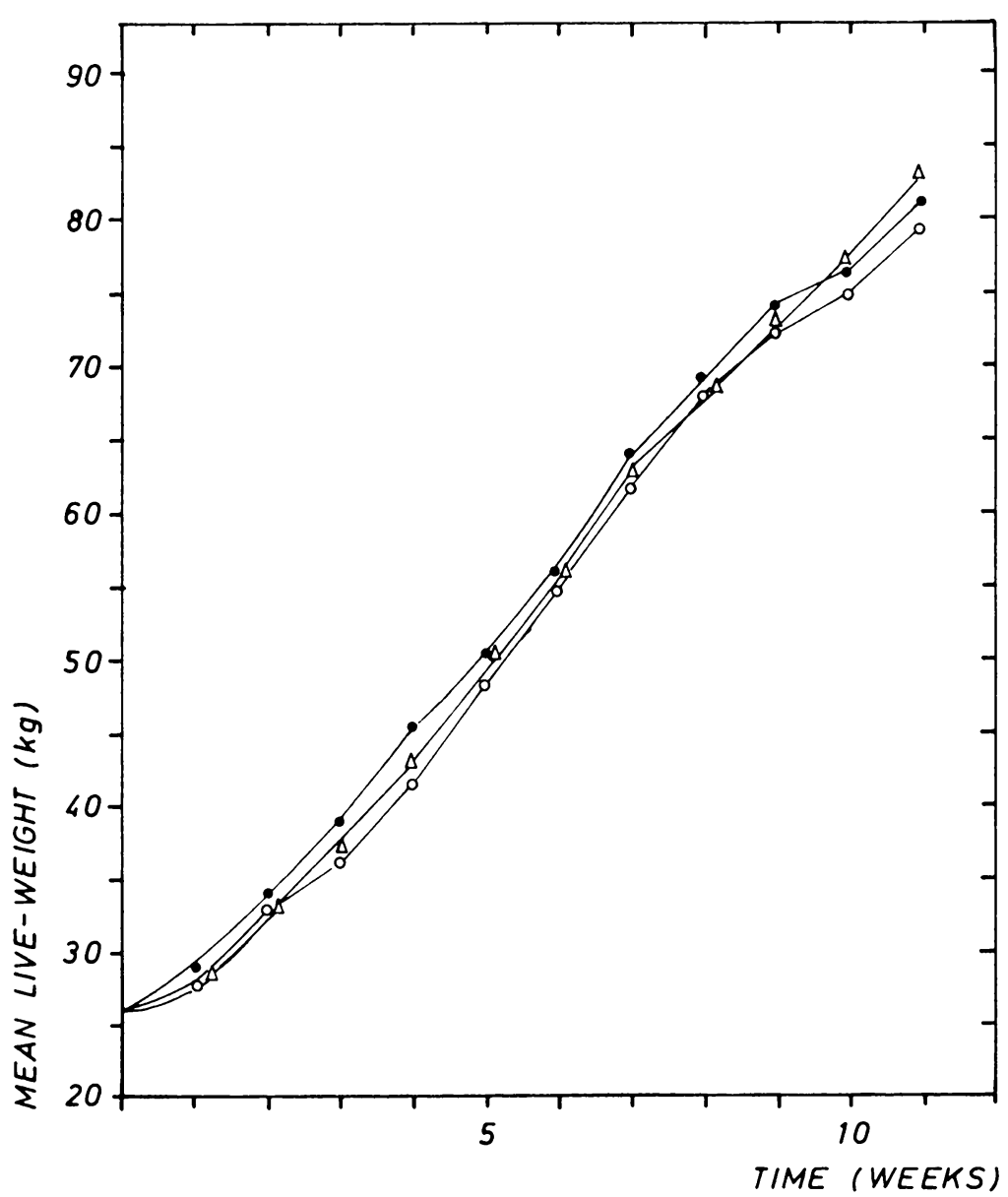

Figure 3. Live-weight of pigs receiving $3 \%(\triangle-\triangle)$ and $6 \%$ (- ) lignosulphonic acids in the diet, and of the control pigs $(\mathrm{O}-\mathrm{O})$.

The colons of all pigs showed some desquamation of the epithelium, and thickening of propria with infiltration of mononuclear cells and eosinophilic granulocytes.

\section{Experiment 2}

The pigs receiving $6 \%$ and $3 \%$ LSA in the diet showed no significant differences in weight gain as compared to the control pigs $(P>0.05)$ (Fig. 3), and they thrived throughout the experimental period of 11 weeks. No diarrhea was observed for any of the pigs. The feces of a few pigs receiving $6 \%$ LSA had, how- 
ever, in the last four weeks of the experiment, a slightly darker colour as compared to the controls. No differences could be detected $(P>0.05)$ in the concentrations of proteinases in the feces of the experimental pigs as compared to the controls.

Necropsy. No significant changes were found by macroscopical and microscopical examinations.

\section{Colour reaction investigations}

Addition of various concentrations of different salts to diluted LSA solutions did not give any colour reactions except for the addition of $\mathrm{FeSO}_{4}$, which resulted in a black solution. When a $2.5 \%$ LSA solution was used, the colour could be measured photometrically with final concentration of $\mathrm{FeSO}_{4}$ as low as $0.0005 \%$.

\section{DISCUSSION}

It was shown in the present investigation that lignosulphonic acids lead to a marked reduction in the weight gain of pigs when given at a concentration of $13 \%$ in the diet. When 6 or $3 \%$ LSA were incorporated in the feed, however, no effect on the weight gain was observed.

The reduction in the weight gain is interesting when seen in relation to the inhibitory effects of LSA on various enzyme systems previously studied (Næss et al. $1973 \mathrm{a}, \mathrm{b}$ ). In these works, it was found that LSA inhibited the proteolytic activities of pepsin, trypsin, $\alpha$-chymotrypsin and a number of microbial proteinases. The higher concentration of nitrogen in the feces of the pigs receiving $13 \% \mathrm{LSA}$ in the diet, as compared to the controls, could be due to decreased digestion of the protein in the feed because of an inhibition of the proteinases in the digestive tract. The higher nitrogen content may also be due to unabsorbed digestive juices (Mitchell 1964). The ability of LSA to form complexes with substances of proteinous nature (Næss 1971) may be of importance in this connection. In addition, an inhibition of the proteinases in the digestive tract, may be a potent stimulus to pancreatic digestive enzyme synthesis, which may result in a pancreatogenous protein-losing enteropathy, as shown by Melmed \& Bouchier (1969) on the basis of experiments with rats and chicken given purified trypsin inhibitors from soybean, ovomucoid and bovine pancreas. The high content of proteolytic enzy- 
mes found in the feces of pigs receiving $13 \%$ LSA in the diet, supports this theory. No signs of hyperactivity of the pancreatic acinar cells as judged by histological examinations were observed, however, in this experiment. The relatively high content of nitrogen in the feces could also be explained by decreased protein digestion due to the diarrhea which the pigs suffered from during most of the 12 weeks of the experiment. The diarrhea may have been caused by a disturbance of the microbial ecosystem of the intestine by LSA, due to inhibition of various biologically active substances as colicins, enzymes and toxins (Næss \& Sandvik 1973) (cf. Rettger 1928; Fredericq 1948). The diarrhea may also have been caused by an irritating effect of LSA on the epithelium of the intestine. Inflammatory reactions were observed in the mucosa of the colon.

Furthermore, the relatively high content of nitrogen in the feces could be explained by fecal loss of blood, which may also result in black feces. Thus the blue colour reaction seen with feces from the pigs when using orthotolidin discs, could indicate the presence of blood. However, as a similar colour reaction was obtained with feces from the control pigs, and even with the different feeds used, these results must be considered with great reservation. Hemorrhages were not observed in the mucosa of the intestine by the microscopical investigations. It seems more probable that the dark colour of the feces is caused by LSA reacting with substances in the feces. The colour reaction demonstrated with LSA and iron may be of importance in this connection.

The diarrhea and the reduced weight gain of the pigs receiving $13 \%$ LSA in the feed may also have been caused by a combination of the factors indicated above.

It is, however, important that high concentration of LSA in the feed is necessary to cause the reduction in weight gain. No decreased weight gain was found when $3 \%$ and $6 \%$ LSA were given in the diets to the pigs. Diarrhea was not observed in any of these pigs either, and they thrived all the time. No obvious changes in the organs were discovered by the microscopical examinations.

Based on the present investigation, it may be concluded that the toxic level of LSA in feed given to growing pigs, seems to be somewhere between 6 and $13 \%$. Other workers (Anon. 1963) have found no difference in the daily weight gain or feed conversion ratio of pigs receiving $0,2.5$ or $4 \%$ of lignin sulphonate 
in the feed, while rations containing $8 \%$ lignin sulphonate depressed the feed intake, daily weight gain and feed conversion ratio. No evidence of toxic effects as a result of the use of lignin sulphonate was found, however. The acceptable upper level of LSA in the feed should, according to the present work, be considered to be lower than $6 \%$, because weak, and small, animals may be more sensitive to LSA than the animals used in this study, bearing in mind the variety of biological systems which may be inhibited, or interfered with, by LSA in the digestive tract.

\section{ACKNOWLEDGEMENTS}

The authors are indebted to Professor Per Slagsvold, Department of Animal Husbandry and Genetics, Veterinary College of Norway, Oslo, and to Møllesentralen i/s, Oslo, Norway, for providing the necessary facilities for the experimental animals.

\section{REFERENCES}

Anonymous: Effect of lignin sulfonate. Feedstuffs 1963, vol. 35, no. 13, 42.

Brüggemann, J., K. H. Niesar \& H. Zucker: Pelletqualität und ihre Beeinflussung durch Presshilfsmittel auf Ligninsulfonatbasis. (Pellet quality, and lignosulphonate as pelletizing agent). Kraftfutter 1964, 1, 10-16.

Eberhardt, W.: Futterverpressung und Presshilfsstoff auf Ligninsulfonatbasis. (Pelleting of fodder, and lignosulphonate as food additive). Kraftfutter 1964, 1, 16-19.

Fossum, K.: Proteolytic enzymes and biological inhibitors I. Comparison between the Kunitz method and the agar gel casein precipitating reaction for determination of the activity of some commercial proteolytic enzymes and inhibtors. Acta path. microbiol. scand. $1970,78 B, 350-362$.

Fredericq, P.: Actions antibiotiques réciproques chez les Enterobacteriaceae. (Antibiotic interactions with Enterobacteriaceae). Rev. belge Path. 1948, 19, Suppl. 4, 1-9.

Heje, $K . K .:$ Lommehåndbok for jordbrukere, skogbrukere, meierister og hagebrukere. (Handbook for farmers, foresters, dairyists and gardeners). Emil Moestue A/S, Oslo 1972, 122.

Hildrum, K. I. \& B. Næss: Gel filtration of lignosulphonic acids and peptide-precipitating abilities of the separated fractions. Acta vet. scand. $1972,13,293-304$.

Jansen, H. P.: Zur Stabilität von Futterpellets. (The stability of feed pellets). Kraftfutter 1, 1964, 20-23. 
Jantzen, L.: Lignoprotein, animal food. Aktieselskapet Christiania Portland Cementfabrik. Brit. 1.092.628. (Cl. C 07 g), Nov. 29, 1967. Appl. Nov. 26, 1964.

Melmed, R. N. \& L. A. D. Bouchier: A further physiological role for naturally occurring trypsin inhibitors: The evidence for a trophic stimulant of the pancreatic ancinar cell. Gut 1969, 10, 973 -979 .

Mitchell, H. H.: Comparative Nutrition of Man and Domestic Animals. Vol. II. Academic Press, New York 1964, 387.

Næss, B.: The precipitation of peptides and proteins by lignosulphonic acids. Acta vet. scand. 1971, 12, 572-582.

Næss, B. \& O. Sandvik: The in vitro effects of peptide-precipitating lignosulphonic acids on various biologically active substances produced by or with action on microorganisms. Acta vet. scand. 1973, 14, 129-146.

Næss, B. \& P. Slagsvold: The nutritive value for growing pigs of single cell protein (Saccharomyces cerevisiae) produced from sulphite spent liquor. Acta vet. scand. 1973, 14, 160-167.

Næss, B., K. Fossum \& O. Sandvik: The effects of peptide-precipitating lignosulphonic acids on the in vitro proteolytic activity of some animal and microbial proteinases. Acta vet. scand. $1973 \mathrm{a}, 14$, $107-117$.

Næss, B., O. Westbye, K. I. Hildrum \& I. Nafstad: The effects of peptideprecipitating lignosulphonic acids on the proteolytic activity of pepsin in vitro and on the response of pigs to an ulcer inducing diet. Acta vet. scand. 1973 b, 14, 44-56.

Oser, B. L.: Hawk's Physiological Chemistry. 14th Ed. McGraw-Hill, New York 1965, 1190.

Pietz, J.: Die biologische Verarbeitung der Sulfitablauge. (The biological treatment of sulphite spent liquor). In Verwertungsgebiete für Sulfitablauge. (Applications of sulphite spent liquor). F. Melms \& K. Schwenzon (ed.). VEB Deutscher Verlag für Grundstoffindustrie. Leipzig 1967, 77-132.

Rettger, L. F.: Bacteria of the intestinal tract. In The Newer Knowledge of Bacteriology and Immunology. E. O. Jordan \& I. S. Falk (ed.). Univ. Chicago Press 1928, 639.

Sandvik, O.: Studies on casein precipitating enzymes of aerobic and facultatively anaerobic bacteria. Thesis. Veterinary College of Norway, Oslo 1962.

\section{SAMMENDRAG}

Virkninger av fóring med peptidpresipiterende ligninsulfonsyrer

$$
i \text { forskjellige konsentrasjoner til griser } i \text { vekst. }
$$

En har vist at når ligninsulfonsyrer blandes med konvensjonelt fór til griser i vekst i konsentrasjon på $13 \%$, resulterer dette i en meget markert nedsetting av tilveksten. 
Når ligninsulfonsyrer ble tilsatt i fóret i mengder på 3 og $6 \%$ fikk en ingen forskjell i tilvekst sammenlignet med kontrollgrisene. En har diskutert den veksthemmende effekt av høge konsentrasjoner av ligninsulfonsyrer i fór sett i relasjon til den tidligere studerte hemmende virkning som slike syrer har på en rekke forskjellige biologiske systemer.

(Received May 31, 1972).

Reprints may be requested from: Bjørn Næss, Department of Microbiology and Immunology, Veterinary College of Norway, Postbox 8146, Oslo Dep., Oslo 1, Norway. 